\title{
Acute diabetes mellitus and its influence on renal Na,K-ATPase in both genders
}

\author{
Veronika Javorková ${ }^{1,2}$, Lucia Mézešová2 Jana Vlkovičová ${ }^{2}$ and Norbert Vrbjar ${ }^{2}$ \\ ${ }^{1}$ Office of Slovak Academy of Sciences, Štefánikova 49, 84219 Bratislava, Slovakia \\ ${ }^{2}$ Institute for Heart Research, Department of Biochemistry, Slovak Academy of Sciences, Bratislava, Slovakia
}

\begin{abstract}
Due to the importance of renal Na,K-ATPase in maintaining the sodium homeostasis in the organism, its activity and abundance is intensively studied in condition of diabetes mellitus. The main subject of this study was the investigation of properties of renal Na,K-ATPase and abundance of its al subunit in view of possible gender-dependent differences in male and female diabetic rats. Diabetes was induced by a single intraperitoneal dose of streptozotocin in a dose of $65 \mathrm{mg} \cdot \mathrm{kg}^{-1}$. The acute diabetes lasting 8 days induced a significant increase in $\mathrm{Na}, \mathrm{K}$-ATPase activity accompanied by significant gender specific increase in $\mathrm{K}_{\mathrm{m}}$ value indicating a worsened affinity of ATP-binding site in female rats. In addition, our present experiments, revealed a significantly higher abundance of renal Na,K-ATPase a 1 subunit in diabetic rats of both genders amounting $94 \%$ increase in males and $107 \%$ in females. But, not all of the newly synthesized enzyme molecules are fully active, as the increase in the number of active molecules is smaller (representing 23\% in males and 20\% in females) as indicated by lower increase in $V_{\max }$ values.
\end{abstract}

Key words: Sodium pump - Hyperglycemia - Streptozotocin - Kidney

\section{Introduction}

In accordance to the world health organization (WHO), 180 million people had diabetes mellitus in 2007, and one of them died approximately every six seconds. Diabetes is accompanied by many complications such as hyperglycemia, ketoacidosis and non-ketotic hyperosmolar coma. Serious long term complications include cardiovascular disease, retinal damage, nerve damage, microvascular damage and chronic renal failure. Diabetic nephropathy is the leading cause of death representing more than $40 \%$ of mortality in diabetic patients. Diabetes induces progressive trends of electrolyte abnormalities as a consequence of failure of chief transport mechanisms in kidney leading to the end-stage renal disease in patients (Shahid and Mahboob 2008). The disease is also often accompanied by hypertension (Landsberg 1994) and altered sodium homeostasis is also a consistent finding in diabetes, as both insulin-dependent and non-insulindependent diabetic patients have a significant increase in

Correspondence to: Norbert Vrbjar, Institute for Heart Research, Department of Biochemistry, Slovak Academy of Sciences, Dúbravská cesta 9, 84005 Bratislava 45, P.O.Box 104, Slovakia E-mail: usrdnorb@savba.sk total exchangeable sodium (O'Hare et al. 1985; Weidmann and Ferrari 1991). The kidney plays an important role in the regulation of blood pressure through modulation of sodium transport across the proximal tubules by the aid of $\mathrm{Na}, \mathrm{K}-\mathrm{ATPase}$ called also as sodium pump. This enzyme is an oligomeric transmembrane protein that establishes and maintains the high internal $\mathrm{K}^{+}$and low internal $\mathrm{Na}^{+}$concentrations typical of most animal cells. By using the energy from the hydrolysis of one molecule of ATP, it transports three $\mathrm{Na}^{+}$ions out in exchange for two $\mathrm{K}^{+}$ions that are taken in. Na,K-ATPase consists of two main subunits, $\alpha$ and $\beta$, and in some tissues including kidney is associated with the third subunit, $\gamma$. The a subunit is a membrane multispanning protein that is responsible for the catalytic and transport properties of the enzyme. This subunit contains binding sites for the cations, ATP, and the inhibitor, ouabain (Pedemonte and Kaplan 1990; Mercer 1993; Lingrel and Kuntzweiler 1994; Pressley 1996; Blanco and Mercer 1998). The $\beta$ subunit is needed for stability, functional maturation, and/or exit of a subunit from the endoplasmatic reticulum (McDonough et al. 1990; Pedemonte and Kaplan 1990; Mercer 1993). Four $\alpha$ isoforms ( $\alpha 1, \alpha 2, \alpha 3$, and $\alpha 4)$ and two $\beta$ isoforms $(\beta 1, \beta 2)$ have been identified in mammals, $\alpha 1$ and $\beta 1$ are the main isoforms of rat kidney (Shull et al. 1986; Sverdlov et al. 1987; 
Martin-Vasallo et al. 1989; Gloor et al. 1990; Shamraj and Lingrel 1994; Appel et al. 1996).

Studies in streptozotocin (STZ)-induced diabetic rats have shown, that changes in the function of renal $\mathrm{Na}, \mathrm{K}$ ATPase depend on the development and the seriousness of the disease in time-dependent manner. In the acute phase of disease after 10 days, the activity and expression of the $\mathrm{Na}, \mathrm{K}-\mathrm{ATP}$ ase was significantly higher in diabetic male rats as compared to the control group (Lal et al. 2000). Previous studies have documented that $\mathrm{Na}, \mathrm{K}$-ATPase is involved in the gender specific protection from the detrimental effects of various diseases and injuries in kidney (Fekete et al. 2004) as well as in the cardiovascular system (Dzurba et al. 1997; Vlkovicova et al. 2005; Sudar et al. 2008). Due to the absence of data concerning the possibility of $\mathrm{Na}$,K-ATPase involvement in possible gender specific protection during diabetes, this present study was designed to investigate the influence of acute diabetes on properties of $\mathrm{Na}, \mathrm{K}$-ATPase. Characterization of kinetic properties of the enzyme and estimation of $\alpha 1$ subunit abundance in male and female rats were used as a tool.

\section{Materials and Methods}

\section{Animal model}

Diabetes mellitus in male and female rats was induced by a single intraperitoneal dose of STZ of $65 \mathrm{mg} \cdot \mathrm{kg}^{-1}$. STZ was dissolved in $0.1 \mathrm{~mol} \cdot \mathrm{l}^{-1}$ citrate buffer, $\mathrm{pH}$ 4.5. The animals were fasted overnight prior to STZ administration. Water and food were available immediately after dosing. Eight days after STZ administration, animals with plasma glucose level higher than $10 \mathrm{mmol} \cdot \mathrm{l}^{-1}$ were considered diabetic and were included in this study. Control groups received a single dose of $0.1 \mathrm{~mol} \cdot \mathrm{l}^{-1}$ citrate buffer. We had four groups. Group FD was acute diabetic group of female rats. Group FC served as a female control. Group MD was acute diabetic of male rats and $\mathrm{MC}$ was control group to diabetic male rats.

During the experiment, the animals were housed in groups of 3 in cages of the type T4 Velaz (Prague, Czech Republic) with bedding composed of wood shaving (exchanged daily). All rats were allowed free access to food and drinking water. The animal room was air-conditioned and the enviroment was continiously monitored for the temperature of $23 \pm$ $1^{\circ} \mathrm{C}$ with relative humidity of $55 \pm 10 \%$. All the experiments were terminated in the age of animals 16 weeks.

At the end of experiment, glucose plasma level was measured by commercial glucose GOD 250 kit (PLIVA-Lachema, Brno, Czech Republic). The kidneys were immediately frozen in liquid nitrogen and stored for further investigations of $\mathrm{Na}, \mathrm{K}$-ATPase properties. All experiments were approved by the Veterinary Council of the Slovak Republic (Decree No. 289, part 139,
July $9^{\text {th }}$ 2003) and they conform with Principles of Laboratory Animals Care (NIH publication 83-25, revised 1985).

\section{Preparation of tissue fractions for kinetic measurements}

The plasmalemmal membrane fraction from kidney was isolated according to Jorgensen (1974). Amount of proteins was determined by the procedure of Lowry et al. (1951) using bovine serum albumin as a standard.

\section{Kinetic measurements of $\mathrm{Na}, \mathrm{K}$-ATPase}

ATP-kinetics of $\mathrm{Na}, \mathrm{K}$-ATPase was estimated at a temperature of $37^{\circ} \mathrm{C}$ measuring the hydrolysis of ATP by $10 \mu \mathrm{g}$ plasmalemmal proteins in the presence of increasing concentrations of substrate ATP $\left(0.16-8.0 \mathrm{mmol} \cdot \mathrm{l}^{-1}\right)$. The total volume of medium was $0.5 \mathrm{ml}$ containing (in mmol. $\mathrm{l}^{-1}$ ): $\mathrm{MgCl}_{2} 4, \mathrm{KCl}$ $10, \mathrm{NaCl} 100$ and imidazole 50 (pH 7.4). After 20 min of pre-incubation in substrate-free medium, the reaction was started by addition of ATP and after 20 min the reaction was stopped by addition of $0.3 \mathrm{ml} 12 \%$ ice-cold solution of trichloroacetic acid. The liberated inorganic phosphorus was determined according to Taussky and Shorr (1953). In order to establish the Na,K-ATPase activity, the ATP hydrolysis that occurred in the presence of $\mathrm{Mg}^{2+}$ only was subtracted.

The Na,K-ATPase kinetics for cofactor $\mathrm{Na}^{+}$was determined by the same method, in the presence of increasing concentration of $\mathrm{NaCl}\left(2.0-100.0 \mathrm{mmol} \cdot \mathrm{l}^{-1}\right)$. The amount of ATP was constant $\left(8 \mathrm{mmol} \cdot \mathrm{l}^{-1}\right)$.

From obtained data by direct nonlinear regression, the following kinetic parameters were evaluated: $V_{\max }, K_{m}$, $\mathrm{K}_{\mathrm{Na}}$. The parameter $\mathrm{V}_{\max }$ represents the maximal velocity, $\mathrm{K}_{\mathrm{m}}$ and $\mathrm{K}_{\mathrm{Na}}$ values represent the concentrations of ATP or $\mathrm{Na}^{+}$necessary for half maximal activation of the enzyme. All results were expressed as mean \pm S.E.M. The significance of differences between the individual groups was determined with using of ANOVA and Bonferroni test. A value of $p<$ 0.05 was regarded as significant.

\section{Preparation of tissue fractions for electrophoresis and immunochemical Western blot analysis}

The tissue samples from kidneys were crushed in liquid nitrogen and consequently re-suspended in ice-cold buffer containing (in mmol. $\mathrm{l}^{-1}$ ): 50 Tris- $\mathrm{HCl}, 250$ sucrose, 1.0 dithiothreitol, 1.0 phenylmethylsulfonylfluoride ( $\mathrm{pH} 7.4$ ) and homogenized with a glass-teflon homogenizer. The homogenates were centrifuged at $800 \times g$ for $5 \mathrm{~min}$ at $4^{\circ} \mathrm{C}$, pellets after this centrifugation were discarded and the supernatants were centrifuged again at $9300 \times g$ for $30 \mathrm{~min}$. The supernatants after this second centrifugation were discarded again and the pellets were re-suspended in homogenizing buffer supplemented with $0.2 \%$ Triton X-100 and centrifuged 
at $9300 \times g$ for $1 \mathrm{~min}$. The Triton X-100 soluble supernatants represented the particulate fractions. The protein concentrations were estimated by the method of Lowry (1951).

\section{Electrophoresis and immunochemical Western blot analysis}

Samples of particular protein fractions containing equivalent amounts of proteins $(90 \mu \mathrm{g})$ per lane were separated by sodium dodecyl sulfate-polyacrylamide gel electrophoresis according to Laemmli (1970). Total contents of a 1 subunits of Na,K-ATPase were estimated by Western blot analysis. For primary immunodetection of al subunit of $\mathrm{Na}, \mathrm{K}$-ATPase, specific anti- $\alpha 1$ antibody (from Sigma) was used. After electrophoretic separation, proteins were transferred to nitrocellulose membrane (Western blot assays). As the secondary antibodies peroxidase-labelled anti-mouse imunoglobulins (Amersham Biosciences) were used. Bound antibodies were detected by the enhanced chemiluminescent method.

Quantification of protein levels was performed using Image J program. Data were expressed as means \pm S.E.M. Statistical significance of differences between the groups was analyzed by the unpaired Student's $t$-test. Differences were considered as significant at $p<0.05$.

\section{Results}

\section{Body weight, kidney weight}

The gain in body weight was lower in both diabetic groups. In MD group this reduction represented 22\% and in FD group $14 \%$ as compared to the respective controls. The kidney weight was unchanged in both diabetic groups investigated. On the other hand, the ratio of kidney weight versus body weight was significantly higher in both diabetic rats as comparing with adequate control groups. In FD group, the ratio was higher by $31 \%$ and in MD group it was higher by $29 \%$ (Table 1 ).

Table 1. Influence of the STZ-induced diabetes mellitus on weight parameters of males and females measured at the end of acute experiments ( 8 days)

\begin{tabular}{|c|c|c|c|}
\hline $\begin{array}{c}\text { Groups of } \\
\text { rats }\end{array}$ & $\begin{array}{c}\mathrm{Bw} \\
(\mathrm{g})\end{array}$ & $\begin{array}{c}\mathrm{Kw}(\mathrm{L}+\mathrm{R}) \\
(\mathrm{mg})\end{array}$ & $\begin{array}{c}\mathrm{Kw}(\mathrm{L}+\mathrm{R}) / \mathrm{Bw} \\
\left({\mathrm{mg} \cdot \mathrm{g}^{-1}}^{-1}\right.\end{array}$ \\
\hline FC & $190 \pm 6$ & $1457 \pm 85$ & $7.7 \pm 0.3$ \\
\hline FD & $163 \pm 7^{\mathrm{a}}$ & $1638 \pm 114$ & $10.0 \pm 0.4^{\mathrm{a}}$ \\
\hline MC & $278 \pm 6$ & $1913 \pm 91$ & $7.3 \pm 0.3$ \\
\hline MD & $216 \pm 4^{\mathrm{b}}$ & $2176 \pm 80$ & $9.4 \pm 0.7^{\mathrm{b}}$ \\
\hline
\end{tabular}

Data represent means \pm SEM at the end of experiment, $n=7$ in all groups. Bw, body weight; $\mathrm{Kw}$, kidney weight; $\mathrm{L}+\mathrm{R}$, left+right; FC, female control rats; FD, female rats with STZ-induced diabetes mellitus; MC, male control rats; $\mathrm{MD}$, male diabetic rats; ${ }^{\mathrm{a}} p<0.005$ as compared to FC group, ${ }^{b} p<0.005$ as compared to MC group.

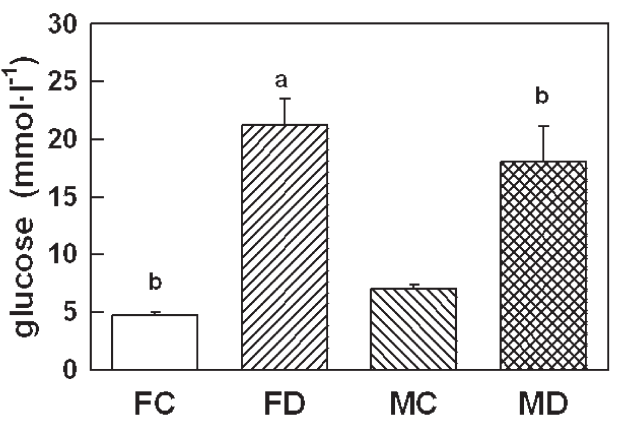

Figure 1. Plasma level of glucose in female control rats (FC), in female rats with STZ-induced diabetes mellitus (FD), in male control rats (MC) and in male diabetic rats (MD). ${ }^{a} p<0.005$ as compared to FC group; ${ }^{b} p<0.005$ as compared to MC group; $n=7$ in all groups.

\section{Level of plasma glucose}

In FC group, the glucose level was lower by $33-45 \%$ as compared to MC group. Administration of STZ resulted in significantly higher level of plasma glucose in both genders. In FD group, the glucose concentration was increased by $351 \%$, and in MD group the increase represented 159\% (Fig. 1).

\section{Kinetic measurements}

Comparison of FC with MC group did not result in variations of kinetic properties of Na,K-ATPase molecule. When activating the enzyme with increasing concentration of ATP or $\mathrm{Na}^{+}$we did not observe any significant alterations of the enzyme activity between the FC and MC groups (Figs. 2 and 4). Consequently, the kinetic parameters for activation of the enzyme with ATP or $\mathrm{Na}^{+}$did not reveal gender-related changes in control animals (Figs. 3 and 5).

Acute diabetes induced significant increase in $\mathrm{Na}, \mathrm{K}$ ATPase activities in both genders. When activating the enzyme with increasing concentration of ATP we observed a slight increase in the enzyme activity in FD as well as in the MC group, as compared to respective controls. However, the above stimulation of $\mathrm{Na}, \mathrm{K}$-ATPase revealed gender specific variations. In female rats, the effect rose up gradually with increasing concentration of ATP, reaching the maximum $(17 \%)$ at $8 \mathrm{mmol} \cdot \mathrm{l}^{-1}$ of ATP. On the other hand, in diabetic males the stimulatory effect decreased with increasing concentration of substrate from $18 \%$ at $0.16 \mathrm{mmol} \cdot \mathrm{l}^{-1}$ to $12 \%$ at $8.0 \mathrm{mmol} \cdot \mathrm{l}^{-1}$ of ATP (Fig. 2). Evaluation of the above data by the method of nonlinear regression resulted in statistically significant increase in $\mathrm{V}_{\max }$ values by $20 \%$ in FD and by $23 \%$ in MD group, as compared to respective controls. The $\mathrm{K}_{\mathrm{m}}$ value 
was significantly increased by $24 \%$ in FD group but in MD group it remained unchanged (Fig. 3).

Direct comparison of FD and MD groups showed higher stimulation of $\mathrm{Na}, \mathrm{K}-\mathrm{ATP}$ ase activity in males. The effect decreased from 38 to $12 \%$ with increasing concentration of substrate in the range $0.16-8.0 \mathrm{mmol} \cdot \mathrm{l}^{-1}$ of ATP (Fig. 2). The $\mathrm{V}_{\max }$ value was increased by $10 \%$ and the $\mathrm{K}_{\mathrm{m}}$ value was lower by $24 \%$ in the MD, as compared to FD group (Fig. 3 ).

When activating the enzyme with increasing concentrations of $\mathrm{NaCl}$ we observed an increase in the enzyme activity in both diabetic groups. In the FD group, the stimulation was constantly $12 \%$ throughout the investigated concentration of $\mathrm{NaCl}$. In the MD group, the increase represented 20\% at the lowest concentration of $\mathrm{NaCl}\left(2 \mathrm{mmol} \cdot \mathrm{l}^{-1}\right)$. With growing concentrations of the cofactor, the effect slightly decreased to $12 \%$ in the presence of the highest concentration of $\mathrm{NaCl}$ (100 mmol. $\mathrm{l}^{-1}$ ) (Fig. 4). Evaluation of the above data by the method of nonlinear regression showed that acute diabetes in rats resulted in increased $V_{\max }$ by $21 \%$ in FD and by $24 \%$ in $\mathrm{MD}$ group. The value of $\mathrm{K}_{\mathrm{Na}}$ remained unchanged by diabetes in both genders (Fig. 5). Direct comparison of FD and MD groups showed slightly higher stimulation (5-9\%) of Na,KATPase activity in males resulting in increased $V_{\text {max }}$ value by $10 \%$ in the MD group (Fig. 4). The $\mathrm{K}_{\mathrm{Na}}$ value did not show gender-dependent changes in FD and MD groups (Fig. 5).

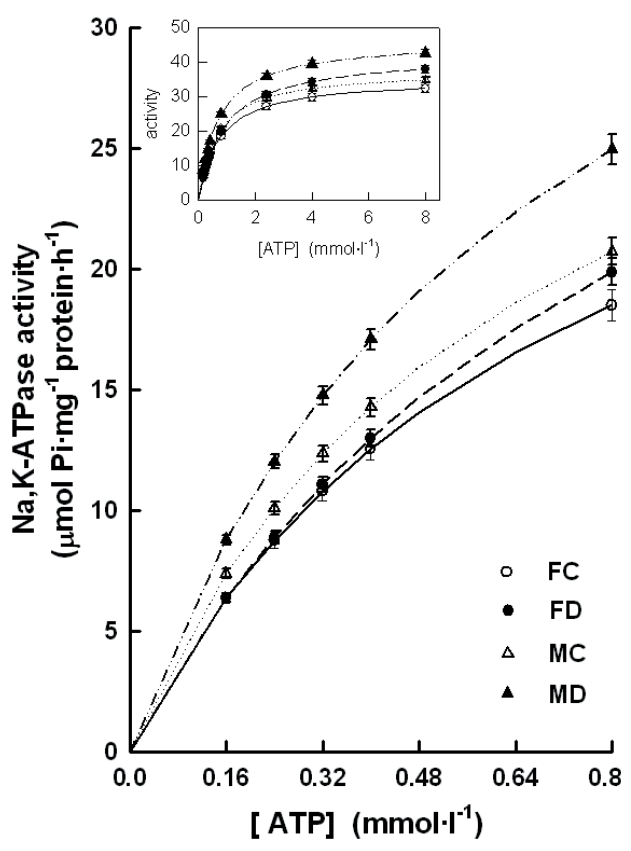

Figure 2. Activation of renal Na,K-ATPase by low concentrations of substrate ATP in female control rats (FC), in female rats with STZ-induced diabetes mellitus (FD), in male control rats (MC) and in male diabetic rats (MD). Insert: activation of the enzyme in the whole investigated concentration range of ATP.

\section{Quantification of Na,K-ATPase $\alpha 1$ subunit}

Direct comparison of abundance of Na,K-ATPase in control groups of both genders resulted in significantly lower presence of $\alpha 1$ subunit by about $16-21 \%$ in FC group. Similarly, comparison of diabetic groups FD vs. MD resulted in significant decrease by about $20 \%$ in the female group as compared to male group. Comparison of particular diabetic groups with their respective controls yielded the following data. Diabetes induced an increase in relative amount of $\mathrm{Na}, \mathrm{K}-\mathrm{ATP}$ ase al subunit in both genders. In males (MD vs. MC), the increase represented $94 \%$ and in females $107 \%$ (FD vs. FC) (Fig. 6).

\section{Discussion}

Recent studies have shown that diabetes induces many different complications throughout the organism, e.g. neuropathy accompanied with decrease in nerve conduction velocity (Skalska et al. 2008), alterations in endothelium and ultrastructure in femoral and mesenteric arteries (Sotnikova et al. 2006), disturbances of plasma lipid metabolism (Vojtasakova et al. 2007; Soulimane-Mokhtari et al. 2008), increase in aldose reductase activity in lens (Djoubisie et al. 2006), decrease in oxidative energy production in the cardiac tissue (Ferko et al. 2006), impaired function of ion transporting Na,K-ATPase in heart (Vlkovicova et al. 2006) and in kidney (Vrbjar et al. 2007).

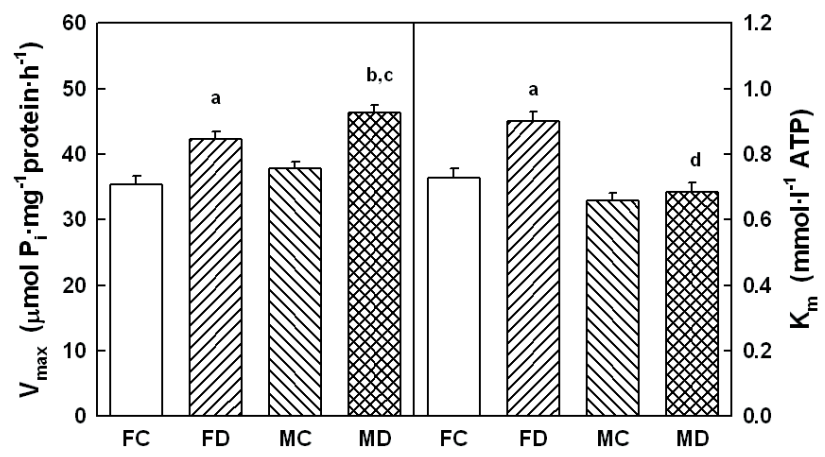

Figure 3. Kinetic parameters of renal $\mathrm{Na}, \mathrm{K}$-ATPase during activation with ATP in female control rats (FC), in female rats with STZ-induced diabetes mellitus (FD), in male control rats (MC) and in male diabetic rats (MD). The parameter $\mathrm{V}_{\max }$ represents the maximal velocity of enzyme reaction, $\mathrm{K}_{\mathrm{m}}$ value refers to the concentration of ATP necessary for half maximal activation of the enzyme. Data represent means \pm S.E.M, $n=9$ in each group. ${ }^{\mathrm{a}} p<0.001$ as compared to the FC group; ${ }^{\mathrm{b}} p<0.001$ as compared to the MC group; ${ }^{\mathrm{c}} p<0.01$ as compared to the FD group; ${ }^{\mathrm{d}} p<0.001$ as compared to the FD group. 


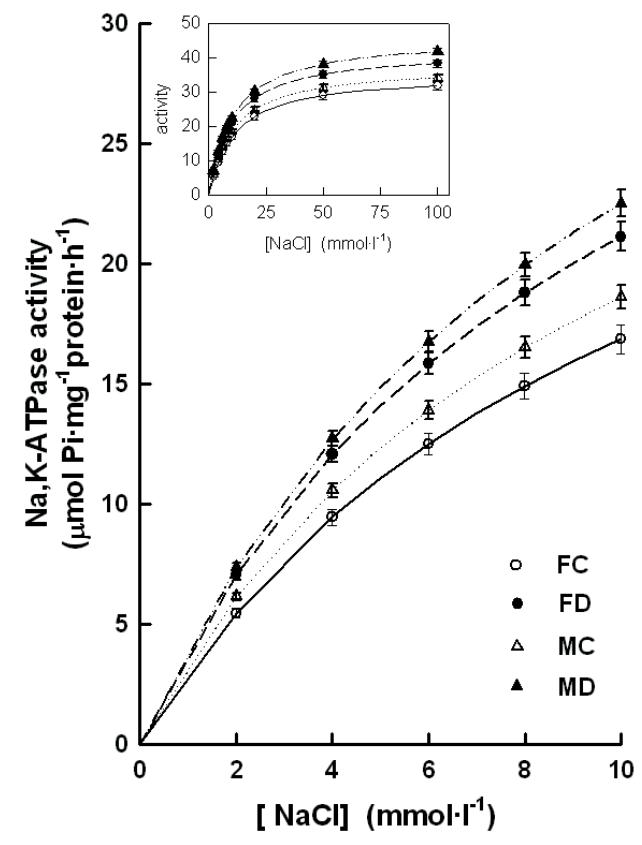

Figure 4. Activation of renal Na,K-ATPase by low concentrations of cofactor $\mathrm{Na}^{+}$in female control rats (FC), in female rats with STZ-induced diabetes mellitus (FD), in male control rats (MC) and in male diabetic rats (MD). Insert: Activation of the enzyme in the whole investigated concentration range of $\mathrm{NaCl}$.

In our experiments, in rats suffering STZ-induced diabetes for 8 days, significant changes in body weight were observed. Previously published studies documented that in acute 7 days lasting STZ-induced diabetes the reduction represented $10 \%$ in male rats when STZ was used in a dose $50 \mathrm{mg} \cdot \mathrm{kg}^{-1}$ (Davel et al. 2000). The $22 \%$ decrease in body weight observed in our acute form of experiment for male diabetic rats may be explained by the higher dose of $65 \mathrm{mg} \cdot \mathrm{kg}^{-1}$ of STZ. The present study

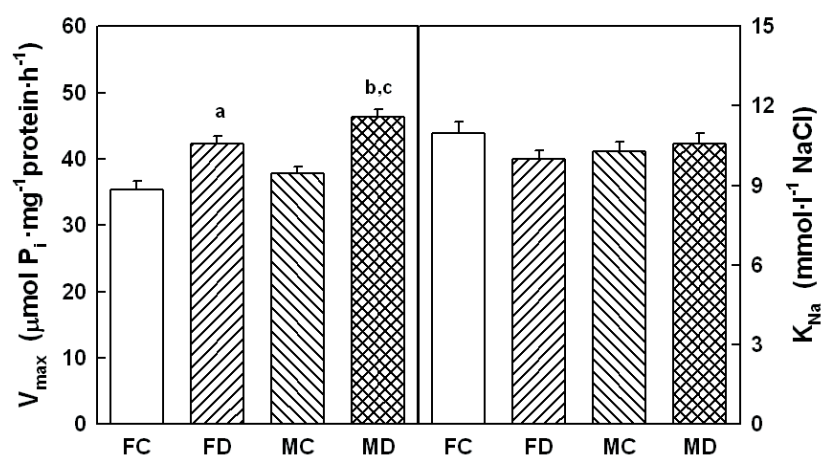

Figure 5. Kinetic parameters of renal Na,K-ATPase during activation with $\mathrm{Na}^{+}$in female control rats (FC), in female rats with STZ-induced diabetes mellitus (FD), in male control rats (MC) and in male diabetic rats $(\mathrm{MD})$. The parameter $\mathrm{V}_{\max }$ represents the maximal velocity of enzyme reaction, $\mathrm{K}_{\mathrm{Na}}$ value refers to the concentration of $\mathrm{Na}^{+}$necessary for half maximal activation of the enzyme. Data represent means \pm S.E.M, $n=9$ in each group. ${ }^{\mathrm{a}} p<$ 0.001 as compared to the FC group; ${ }^{\mathrm{b}} p<0.001$ as compared to the $\mathrm{MC}$ group; ${ }^{\mathrm{c}} p<0.01$ as compared to the FD group.

brings an indication about a probable gender specific effect in female rats as the loss in weight gain was significantly lower in female diabetic rats amounting $14 \%$ only. The explanation of the mechanism of the above effect remains unclear and needs further investigation. Even if the relative kidney weight (kidney weight / body weight ratio) was significantly increased by acute form of diabetes, the unchanged kidney weight in both genders excluded the suspicion of renal hypertrophy. The relative kidney weight seems to be changed only due to lower body weight in diabetic groups of both genders.

The main aim of the present study was to establish whether acute STZ-induced diabetes in rats is followed by

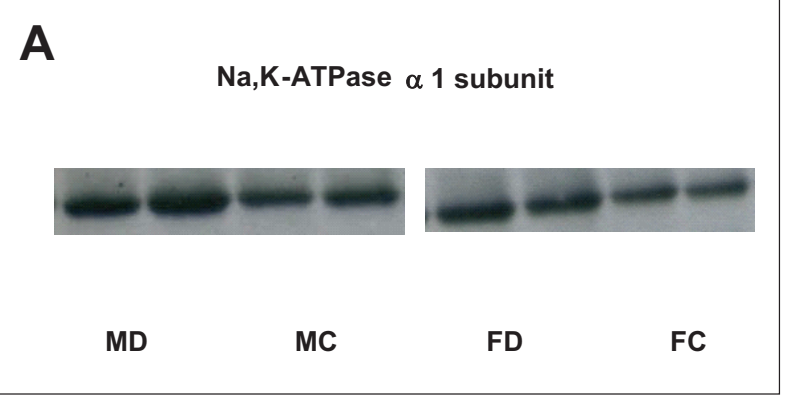

B

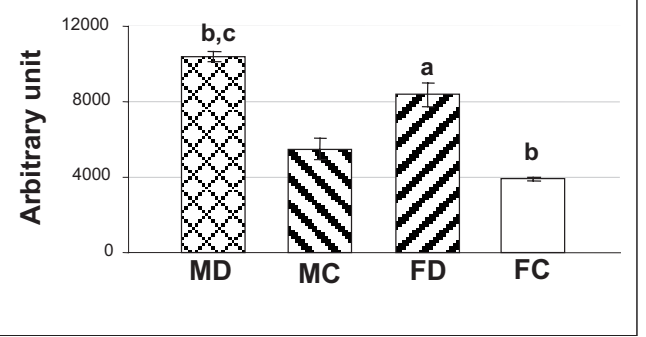

Figure 6. A. Immunoblot analysis. B. Relative densities of bands. Relative abundance of Na,K-ATPase al subunit in kidney after acute diabetes in female control rats (FC), in female rats with STZ-induced diabetes mellitus (FD), in male control rats (MC) and in male diabetic rats (MD). ${ }^{a}$ as compared to the FC group; ${ }^{b}$ as compared to the MC group; ${ }^{c} p<0.01$ as compared to the FD group; $n=4$ in all groups. 
any functional changes of renal $\mathrm{Na}, \mathrm{K}$-ATPase. Renal epithelial cells contain high densities of mitochondria necessary to produce sufficient ATP for the active transport of $\mathrm{Na}^{+}$ions. Approximately $90 \%$ of oxygen extracted by mitochondria in the kidney is used for the work required for $\mathrm{Na}^{+}$reabsorption in the nephron (Welch 2006). Due to the importance of renal $\mathrm{Na}, \mathrm{K}-\mathrm{ATPase}$ in maintaining the sodium homeostasis in the organism, its activity and abundance is intensively studied in condition of diabetes.

Our studies of the kinetics of Na,K-ATPase revealed gender specific changes in qualitative properties of the enzyme during the acute diabetes. In female rats, hyperglycemia induced deterioration of the affinity of the ATP binding site in the enzyme molecule as indicated by increased $K_{m}$ value. In male rats, the ATP binding site of the enzyme was resistant to diabetes-induced complications as suggested by unchanged value of $\mathrm{K}_{\mathrm{m}}$. In this context may be interesting the fact that in female rats the same dose of STZ was followed by two-fold increase in blood glucose level as compared to male rats (351\% in FD group vs. $159 \%$ in MD group). This gender specific difference in hyperglycemia may be responsible for the worsening of ATP binding properties of $\mathrm{Na}$, K-ATPase in female rats. The diabetes-induced conformational changes of the enzyme molecule in female rats are probably restricted to the cytoplasmic loop of the enzyme containing the ATP binding site. The sodium binding site localized nearby the intracellular surface of the cell membrane seems to be unaffected as suggested by unchanged value of $\mathrm{K}_{\mathrm{Na}}$.

Concerning the quantity of enzyme our study offers two series of information about $\mathrm{Na}, \mathrm{K}$-ATPase during acute diabetes in the renal tissue. First information is given by Western blot analysis and the second information is given by analysis of $V_{\max }$ values obtained from kinetic studies. Since $\mathrm{V}_{\max }$ is independent of substrate concentration, it provides information about the changes in number of active enzyme molecules in the renal tissue. Acute diabetes induced higher enzyme activity accompanied with significant increase in the $V_{\max }$ value suggesting enhanced number of active $\mathrm{Na}, \mathrm{K}$-ATPase molecules in both genders. This hypothesis is supported by increased abundance of Na,K-ATPase al subunit in diabetic male as well as female rats as documented by presented Western blots. Up to our knowledge there is a lack of information about diabetes-induced alterations of the $\mathrm{Na}, \mathrm{K}$-ATPase in females. Our data of significant increase in the level of al subunit induced by acute form of diabetes in male rats are in agreement with previous observations about a significant increase in the activity and expression of the enzyme as a consequence of acute diabetes (Lal et al. 2000; Scherzer and Popovtzer 2002). The above changes of the enzyme in kidney seem to be a tissue specific process, as the enzyme in cardiac tissue as well as in the vascular smooth muscle revealed significant decrease in activity and the amount of $\alpha 1$ subunit (Ziegelhoffer et al. 1996; Ver et al. 1997; Davel et al. 2000). The observed accumulation of $\mathrm{Na}, \mathrm{K}$-ATPase al subunit in kidney supports its importance in adaptation to complications induced by acute diabetes, as it was hypothesized by $\mathrm{Ku}$ et al. (1986). Since $\mathrm{Na}, \mathrm{K}-$ ATPase-mediated ion transport is the major consumer of metabolic energy in the kidney, utilizing about $20-30 \%$ of ATP production (Jorgensen and Pedersen 2001), the enzyme is critically important to renal function. It may be suggested that the increase in activity and abundance of renal $\mathrm{Na}, \mathrm{K}$ ATPase observed in acute form of diabetes is an essential component of the renal hyperfunction seen in this disease and may represent an important adaptive change in response to hyperglycemia.

An other important subject of this study was the investigation of amounts of $\mathrm{Na}, \mathrm{K}$-ATPase a 1 subunit in view of possible gender dependent differences in male and in female rats. Our data showed that the abundance of $\alpha 1$ subunit is significantly higher in control male rats as compared to females. This may be explained by probable contribution of 17- $\beta$ estradiol in regulation of Na,K-ATPase synthesis in the renal tissue. Previously it was shown that administration of $17-\beta$ estradiol to non-diabetic ovariectomized rats decreased the abundance of $\mathrm{Na}, \mathrm{K}$-ATPase $\alpha 1$ subunit in the outer medulla (Riazi et al. 2006). In view of higher expression of $\mathrm{Na}, \mathrm{K}$-ATPase al subunit in males, it could be expected that the number of active enzyme molecules would be also increased. However, the present data demonstrated, that the number of active enzyme molecules seems to be comparable in both genders as suggested by similarities of $\mathrm{V}_{\max }$ values in control male and female rats. So, the excessively expressed molecules of $\alpha 1$ subunit in male rats are probably not fully active.

The diabetes-induced increased expression of $\alpha 1$ subunit in both genders (amounting 94\% in males and $107 \%$ in females) is followed by increased activity of the enzyme. But in this elevation of the activity not all of the newly synthesized enzyme molecules are involved as the increase in the number of active molecules is smaller (representing $23 \%$ in males and $20 \%$ in females) as indicated by increased $\mathrm{V}_{\max }$ values.

In summary, our present data provide an evidence for higher abundance of $\mathrm{Na}, \mathrm{K}$-ATPase al subunit in renal tissue of control male rats as compared to respective female group. Acute diabetes induced higher expression of $\mathrm{Na}, \mathrm{K}$-ATPase al subunit in both genders, but not all of the newly synthesized enzyme molecules were fully active, as suggested by our kinetic studies.

Acknowledgements. The present study was supported by the grants European Social Foundation JPD 3BA 2005/1-031 and by Slovak Grant Agency VEGA 2/7127/27. The authors thank to Mrs. E. Havránková and Mrs. Z. Hradecká for their careful technical assistance. 


\section{References}

Appel C., Gloor S., Schmalzing G., Schachner M., Bernhardt R. R. (1996): Expression of Na,K-ATPase $\beta 3$ subunit during development of the zebrafish central nervous system. J. Neurosci. Res. 46, 551-564

Blanco G., Mercer R. W. (1998): Isoenzymes of the Na,K-ATPase: heterogenity in structure, diversity in function. Am. J. Physiol. 275, F633-650

Davel A. P. C., Rossoni L. V., Vassallo D. V. (2000): Effects of ouabain on the presor response to phenylephrine and on the sodium pump activity in diabetic rats. Eur. J. Pharmacol. 406, 419-427

Djoubissie P.-O., Snirc V., Sotnikova R., Zurova J., Kyselova Z., Skalska S., Gajdosik A., Javorkova V., Vlkovicova J., Vrbjar N., Stefek M. (2006): In vitro inhibition of lens aldose reductase by (2-benzyl-2,3,4,5-tetrahydro- $1 \mathrm{H}$ pyrido[4,3-b]indole-8-yl)-acetic acid in enzyme preparations isolated from diabetic rats. Gen. Physiol. Biophys. 25, 415-425

Dzurba A., Ziegelhoffer A., Vrbjar N., Styk J., Slezak J. (1997): Estradiol modulates the sodium pump in the heart sarcolemma. Mol. Cell. Biochem. 176, 113-118

Fekete A., Vannay A., Ver A., Vasarhelyi B., Muller V., Ouyang N., Reusz G., Tulassay T., Szabó A. J. (2004): Sex differences in the alterations of $\mathrm{Na}, \mathrm{K}$-ATPase following ischaemiareperfusion injury in the rat kidney. J. Physiol. 555, 471-480

Ferko M., Gvozdjaková A., Kucharská J., Mujkošová J., Waczulíková I., Styk J., Ravingerová T., ZiegelhöfferMihalovičová B., Ziegelhöffer A. (2006): Functional remodeling of heart mitochondria in acute diabetes: in terrelationships between damage, endogenous protection and adaptation. Gen. Physiol. Biophys. 25, 397-413

Gloor S., Antonicek H., Sweadner K. J., Pagliusi S., Frank R., Moos M., Schachner M. (1990): The adhesion molecule on glie (AMOG) is a homologue of the $\beta$ subunit of the $\mathrm{Na}, \mathrm{K}-\mathrm{ATP}$ ase. J. Cell Biol. 110, 165-174

Jorgensen P. L., Pedersen P. A. (2001): Structure-function relationships of $\mathrm{Na}, \mathrm{K}$, ATP, or Mg binding and energy transduction in Na,K-ATPase. Biochim. Biophys. Acta $1505,57-74$

Jorgensen P. L. (1974): Purification and characterization of $\left(\mathrm{Na}^{+}, \mathrm{K}^{+}\right)$-ATPase. III. Purification from the outer medulla of mammalian kidney after selective removal of membrane components by sodium dodecylsulphate. Biochim. Biophys. Acta 356, 36-52

Ku D. D., Sellers B. M., Meezan E. (1986): Development of renal hypertrophy and increased renal $\mathrm{Na}, \mathrm{K}$-ATPase in streptozotocin-diabetic rats. Endocrinology 119, 672-679

Laemmli U. K. (1970): Cleavage of structural proteins during the assembly of the head bacteriophage. Nature 227, 680-685

Lal M. A., Körner A., Matsuo Y., Zelenin S., Cheng S. X., Jaremko G., DiBona G. F., Eklöf A. C., Aperia A. (2000): Combined antioxidant and COMT inhibitor treatment reverses renal abnormalities in diabetic rats. Diabetes 49, 1381-1390
Landsberg L. (1994): Pathophysiology of obesity-related hypertension: role of insulin and the sympathetic nervous system. J. Cardiovasc. Pharmacol. 23 (Suppl. 1), S1-8

Lingrel J. B., Kuntzweiler T. (1994): Na,K-ATPase. J. Biol. Chem. 269, 19659-19662

Lowry O. H., Rosebrough N. J., Farr A. L., Randall R. J. (1951): Protein measurement with the folin phenol reagent. J. Biol. Chem. 193, 265-275

Martin-Vasallo P., Dackowski W., Emanuel J. R., Levenson R. (1989): Identification of a putative isoform of the $\mathrm{Na}, \mathrm{K}$ ATPase $ß$ subunit. Primary structure and tissue-specific expression. J. Biol. Chem. 264, 4613-4618

McDonough A. A., Geering K., Farley R. A. (1990): The sodium pump needs its ß subunit. FASEB J. 4, 1598-1605

Mercer R. W. (1993): Structure of the Na,K-ATPase. Int. Rev. Cytol. 137, 139-168

O’Hare J. A., Ferris J. B., Brady D., Twomey B., O’Sullivan D. J. (1985): Exchangeable sodium and renin in hypertensive diabetic patients with and without nephropathy. Hypertension 7 (Suppl. 2), 43-48

Pedemonte C. H., Kaplan J. H. (1990): Chemical modification as an approach to elucidation of sodium pump structurefunction relations. Am. J. Physiol. 258, C1-23

Pressley T. A. (1996): Structure and function of the Na,K pump: ten years of molecular biology. Miner. Electrolyte Metab. 22, 264-271

Riazi S., Maric C., Ecelbarger C. A. (2006): 17-ß estradiol attenuates streptozotocin-induced diabetes and regulates the expression of the renal sodium transporters. Kidney Int. 69, $471-480$

Shahid S. M., Mahboob T. (2008): Electrolytes and Na,K-ATPase: potential risk factors for the development of diabetic nephropathy. Pak. J. Pharm. Sci. 21, 172-179

Shamraj O. I., Lingrel J. B. (1994): A putative fourth Na,K-ATPase a subunit gene is expressed in testis. Proc. Natl. Acad. Sci. U.S.A. 91, 12952-12956

Shull G. E., Greeb J., Lingrel J. B. (1986): Molecular cloning of three distinct forms of the $\mathrm{Na}, \mathrm{K}$-ATPase $\alpha$ subunit from rat brain. Biochemistry 25, 8125-8132

Scherzer P., Popovtzer M. M. (2002): Segmental localization of mRNAs ancoding $\mathrm{Na}, \mathrm{K}$-ATPase $\alpha 1$ and $\beta 1$-subunits in diabetic rat kidneys using RT-PCR. Am. J. Physiol. 282, F492-500

Skalska S., Kyselova Z., Gajdosikova A., Karasu C., Stefek M., Stolc S. (2008): Protective effect of stobadine on NCV in streptozotocin-diabetic rats: augmentation by vitamin $\mathrm{E}$. Gen. Physiol. Biophys. 27, 106-114

Sotnikova R., Skalska S., Okruhlicova L., Navarova J., Kyselova Z., Zurova J., Stefek M., Hozova R., Nosalova V. (2006): Changes in the function and ultrastructure of vessels in the rat model of multiple low dose streptozotocin-induced diabetes. Gen. Physiol. Biophys. 25, 289-302

Soulimane-Mokhtari N. A., Guermouche B., Saker M., Merzouk S., Merzouk H., Hichami A., Madani S., Khan N. A., Prost J. (2008): Serum lipoprotein composition, lecithin cholesterol acyltransferase and tissue lipase activities in pregnant diabetic rats and their offspring receiving enriched n-3 PUFA diet. Gen. Physiol. Biophys. 27, 3-11 
Sudar E., Velebit J., Gluvic Z., Zakula Z., Lazic E., VuksanovicTopic L., Putnikovic B., Neskovic A., Isenovic E. R. (2008): Hypothetical mechanism of sodium pump regulation by estradiol under primary hypertension. J. Theor. Biol. 251, 584-592

Sverdlov E. D., Monastyrskaya G. S., Broude N. E., Ushkaryov Yu. A., Allikmets R. L., Melkov A. M., Smirnov Yu. V., Malyshev I. V., Dulobova I. E., Petrukhin K. E. (1987) The family of human Na,K-ATPase genes. No less then five genes and/or pseudogenes related to the $\alpha$-subunit. FEBS Lett. 217, 275-278

Taussky H. H., Shorr E. E. (1953): A microcolorimetric method for the determination of inorganic phosphorus. J. Biol. Chem. 202, 675-685

Ver A., Szanto I., Banyasz T., Csermely P., Vegh E., Somogyi J. (1997): Changes in the expression of $\mathrm{Na}^{+} / \mathrm{K}^{+}$-ATPase isoenzymes in the left ventricle of diabetic rat hearts: effect of insulin treatment. Diabetologia 40, 1255-1262

Vrbjar N., Strelková S., Javorková V., Vlkovičová J., Mézešová L., Štefek M., Kyselová Z., Gajdošíková A. (2007): Effect of the pyridoindole antioxidant stobadine on ATP-utilisation by renal $\mathrm{Na}, \mathrm{K}$-ATPase in rats with streptozotocininduced diabetes. Gen. Physiol. Biophys. 26, 207-213

Vlkovicova J., Javorkova V., Pechanova O., Vrbjar N. (2005): Gender difference in functional properties of $\mathrm{Na}, \mathrm{K}$-ATPase in the heart of spontaneously hypertensive rats. Life Sci. 76, 971-982

Vlkovičová J., Javorková V., Štefek M., Kysel’ová Z., Gajdošíková A., Vrbjar N. (2006): Effect of the pyridoindole antioxidant stobadine on the cardiac $\mathrm{Na}^{+}, \mathrm{K}^{+}$-ATPase in rats with streptozotocin-induced diabetes. Gen. Physiol. Biophys. $25,111-124$

Vojtaššáková E., Syneková M., Ťažká D., Mátyáš Š., Hózová R., Sadloňová I., Švec P. (2007): Effect of VULM 1457, an ACAT inhibitor, on serum lipid levels and on real time red blood cell flow in diabetic and non-diabetic hamsters fed high cholesterol-lipid diet. Gen. Physiol. Biophys. 26, 254-259

Weidmann P., Ferrari P. (1991): Central role of sodium in hypertension in diabetic subjects. Diabetes Care 14, 220-232

Welch W. J. (2006): Intrarenal oxygen and hypertension. Clin. Exp. Pharmacol. Physiol. 33, 1002-1005

Ziegelhöffer A., Ravingerová T., Styk J., Tribulová N., Volkovová K., Šeboková J., Breier A. (1996): Diabetic cardiomyopathy in rats: biochemical mechanisms of increased tolerance to calcium overload. Diabetes Res. Clin. Pract. 31 (Suppl. 1), S93-103

Received: July 24, 2008

Final version accepted: November 27, 2008 